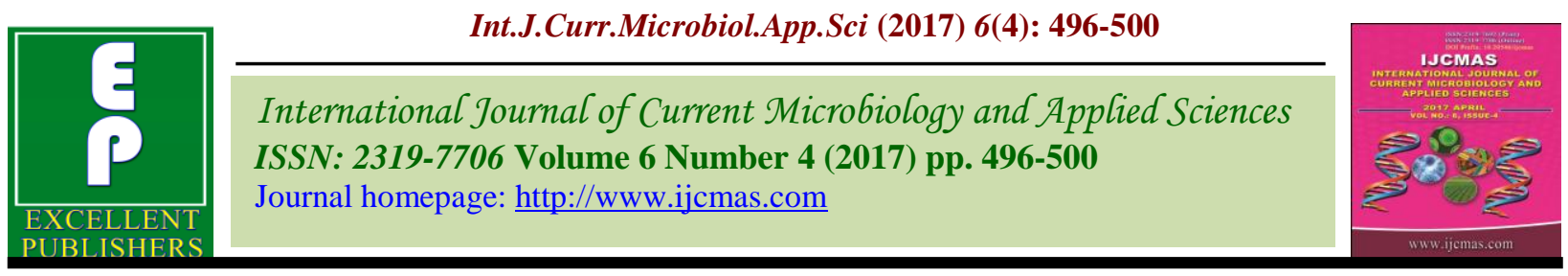

Original Research Article

https://doi.org/10.20546/ijcmas.2017.604.059

\title{
Haematological Alterations in Broilers Administered with Imidacloprid and Spinosad and Its Amelioration with Vitamin E and Silymarin
}

\author{
V. Ravikanth ${ }^{1 *}$, M. Lakshman ${ }^{2}$, D. Madhuri ${ }^{1}$ and B. Kalakumar ${ }^{3}$ \\ ${ }^{1}$ Department of Veterinary Pathology, C.V.Sc, Korutla, India \\ ${ }^{2}$ RUSKA Labs, Department of Veterinary Pathology, C.V.Sc, Hyderabad, India \\ ${ }^{3}$ Department of Veterinary Pharmacology and Toxicology, C.V.Sc, Hyderabad, India \\ *Corresponding author
}

\begin{abstract}
A B S T R A C T
Keywords

Imidacloprid, Spinosad, Male

Cobb broilers,

Toxicity,

Hematological

parameters.

Article Info

Accepted:

02 March 2017

Available Online:

10 April 2017

The present study was aimed to know the heamatological alteration due to imidacloprid and spinosad (neonicotinoid and bacterial insecticide respectively) and their amelioration with vitamin $\mathrm{E}$ and silymarin in male Cobb broiler chicken. The experiment was carried out for 28 days. Group 1 served as control, group 2 treated with imidacloprid @ 50 ppm in feed, group 3 was treated with spinosad @ 1000 ppm in feed, group 4 was treated with imidacloprid@50 ppm and spinosad @ 1000 ppm in feed, group 5 was treated with imidacloprid @50 ppm, spinosad @1000 ppm and Vitamin E @ 20 ppm in feed and group 6 was treated with imidacloprid @ 50 ppm, spinosad @1000 ppm and silymarin @ $1000 \mathrm{ppm}$ in feed. The weekly body weight gains were significantly $(\mathrm{P}<0.05)$ decreased in groups 2, 3 and 4, 5 and 6. Haematological observations revealed a significant $(\mathrm{P}<$ 0.05 ) decrease in overall means of TEC, Hb concentration, MCV, MCH, MCHC and PCV except TLC in groups 2, 3 and 4, 5 and 6 in which there is a significant $(P<0.05)$ increase. These results revealed that exposure of imidacloprid, spinosad and its combination resulted in alterations in haematological parameters.
\end{abstract}

\section{Introduction}

Earlier poultry was restricted to households only, but with a huge increase in demand for poultry products like chicken and eggs are attributed to increasing population with improved scientific knowledge; now poultry has grown into an industry which is contributing to the state economy. The output of the poultry industry is dependent on the source of balanced feed availability. As per NRC (1994) recommendations major portion of feed should contain grains like maize and sorghum as a source of energy and soya, groundnut and cotton seed cake as a source of vegetable protein. Over a period of time, in the resume of success of green revolution the usage of insecticides and pesticides has been enormously increased in grain crop cultivation. However, their indiscriminate use lead to widespread concern because of their potential adverse effect on animal and human health (Al-saleh, 1994). Among all spinosad which is a bacterial insecticide introduced in market in 1997 has high efficacy, with broad insect pest spectrum, low mammalian toxicity and a good environmental profile, which is having a unique feature of the insecticides that are currently used for the protection of grain products (Hertlain et al., 2011). 
Imidacloprid is a potent and most widely used insecticide introduced in the market in 1991 (Yamamoto and Casida, 1999). In view of the significant adverse effects induced by SPD and IM, the current study was designed to observe and evaluate the mixed toxicity and its effect in broiler chicken and to study the ameliorative effect of vitamin $\mathrm{E}$ and silymarin to overcome the mixed toxic effects.

\section{Materials and Methods}

In the present experiment, a total of 120 day old male broiler chicks (Cobb strain) weighing between $32-34 \mathrm{~g}$ were procured from a commercial hatchery. On arrival, the chicks were individually weighed, wing banded and divided into six groups of 20 each. The chicks were housed in battery brooders located at poultry experimental station (PES) and maintained under identical conditions throughout the course of experiment. The experiment was conducted with prior approval of the Institutional Animal Ethics Committee (IAEC).

The experimental design adopted for the present study is shown in table 1 .

All birds have free access to fresh feed and water ad libitum throughout the experimental period.

\section{Chemicals}

Imidacloprid was procured from a wholesale pesticide outlet in Hyderabad under the trade name victor plus $(70 \%$ Imidacloprid $)$, similarly Spinosad was also procured and the trade name is Spinctor $(45 \%$ Spinosad) manufactured by Bayer India Pvt. Ltd., Maharashtra. Vitamin E was obtained from Merck Company and Silymarin was purchased from a medical outlet under the trade name silybon-140 (each tablet contains 140mg of Silymarin).

\section{Growth rate}

Individual body weights of all the birds were recorded by using electronic balance on day one and subsequently on 7th, 14th, 21st and 28th day of experiment to study the body weight gains.

\section{Haematology}

\section{Collection of blood for haematological parameters}

From each group, 6 birds were sacrificed on 14th day and remaining was sacrificed on 28th day. The selected birds were put to fast for 12 hours a day before sacrifice, $3 \mathrm{ml}$ of blood was collected from wing vein in an anticoagulant coated vaccutainers [(K3EDTA tube, $13 \mathrm{~mm} \times 75 \mathrm{~mm}, 4 \mathrm{ml}$ (Rapid Diagnostics Pvt, Ltd., Delhi)] to carry out all haematological parameters viz. Total erythrocyte count (TEC), Total leukocyte count (TLC), Haemoglobin (Hb) concentration, Packed cell volume (PCV), Mean corpuscular hemoglobin $(\mathrm{MCH})$, Mean Corpuscular Volume (MCV) and Mean corpuscular hemoglobin concentration (MCHC) by using automatic whole blood analyzer (Huma count, med source ozone biochemical Pvt. Ltd) and the results obtained were tabulated for statistical analysis by applying one way ANOVA using statistical package for social sciences (SPSS) version 16.0. Differences between means were tested by using Duncan "s multiple comparison tests and significance level was set at $\mathrm{P}<0.05$ (Snedecor and Cochran, 1994).

\section{Results and Discussion}

The present study was carried out to study the individual and mixed toxic effects of imidacloprid and spinosad in birds and their amelioration with vitamin $\mathrm{E}$ and silymarin. 


\section{Body weight}

There is a significant reduction in body weight in group 2,3 and 4 when compared to control This decrease in body weight gain is due to decreased feed and water intake as a result of hepato, renal toxicity. The findings in group 2 and 3 are in agreement with Sasidhar Babu et al., (2014) and Mansour et al., (2007). In amelioration groups i.e. group 5 and 6 showed a significant improvement in comparison with group 4 indicating the protective action of ameliorating agents.

\section{Haematological parameters}

There is a significant $(\mathrm{P}<0.05)$ decrease in haematological parameters like TEC, $\mathrm{Hb}$,
$\mathrm{PCV}, \mathrm{MCV}, \mathrm{MCH}$ and $\mathrm{MCHC}$ in group 2, 3 and 4 when compared to control and numerical increase is noticed in group 5 and 6 compared to group 4 which is statistically insignificant (Tables 3 and 4). These observations were similar to the findings of Yano et al., (2002), Mansour et al., (2007) and Soujanya et al., (2013) in different animals at different dose and time intervals. In the present study, decreased values of TEC, $\mathrm{Hb}, \mathrm{PCV}, \mathrm{MCV}, \mathrm{MCH}$, and $\mathrm{MCHC}$ could be due to the toxic effects of IM, SPD and its combination as direct action on bone marrow, liver and kidney which might play a vital role in haemopoiesis and erythropoietin (EPO) production in respective organs.

Table.1 The experimental design

\begin{tabular}{|l|l|l|}
\hline GROUP & No. of birds & Treatment \\
\hline 1 & 20 & Control \\
\hline 2 & 20 & Imidacloprid @ 50 PPM in feed \\
\hline 3 & 20 & Spinosad @ 1000 PPM in feed \\
\hline 4 & 20 & $\begin{array}{l}\text { Imidacloprid @ 50 PPM + Spinosad @ 1000 PPM } \\
\text { in feed }\end{array}$ \\
\hline 5 & 20 & $\begin{array}{l}\text { Imidacloprid @ 50 PPM + Spinosad @ 1000 PPM + } \\
\text { Vitamin E @ 20 PPM in feed }\end{array}$ \\
\hline 6 & 20 & $\begin{array}{l}\text { Imidacloprid @ 50 PPM + Spinosad @ 1000 PPM + } \\
\text { Silymarin @ 1000 PPM in feed }\end{array}$ \\
\hline
\end{tabular}

Table.2 Weekly body weight gain (g) in different groups

\begin{tabular}{|l|l|l|l|l|}
\hline Group & Day 7 & Day 14 & Day 21 & Day 28 \\
\hline Group 1 & $110.88 \pm 1.28^{\mathrm{a}}$ & $156.6 \pm 8.72^{\mathrm{a}}$ & $367.68 \pm 16.17^{\mathrm{a}}$ & $366.28 \pm 31.55^{\mathrm{a}}$ \\
\hline Group 2 & $100.9 \pm 1.96^{\mathrm{b}}$ & $126.27 \pm 8.33^{\mathrm{b}}$ & $312.61 \pm 17.64^{\mathrm{b}}$ & $264.34 \pm 6.85^{\mathrm{b}}$ \\
\hline Group 3 & $100.05 \pm 2.19^{\mathrm{b}}$ & $125.15 \pm 2.85^{\mathrm{b}}$ & $297.66 \pm 7.37^{\mathrm{b}}$ & $264.11 \pm 2.96^{\mathrm{b}}$ \\
\hline Group 4 & $87.53 \pm 4.78^{\mathrm{c}}$ & $100.6 \pm 10.54^{\mathrm{c}}$ & $202.62 \pm 18.91^{\mathrm{c}}$ & $204.86 \pm 4.04^{\mathrm{c}}$ \\
\hline Group 5 & $99.03 \pm 1.02^{\mathrm{b}}$ & $123.72 \pm 3.49^{\mathrm{b}}$ & $256.55 \pm 25.66^{\mathrm{b}}$ & $276.70 \pm 28.53^{\mathrm{b}}$ \\
\hline Group 6 & $97.55 \pm 2.79^{\mathrm{b}}$ & $123 \pm 5.25^{\mathrm{b}}$ & $264.76 \pm 14.99^{\mathrm{b}}$ & $273.51 \pm 15.38^{\mathrm{b}}$ \\
\hline P value & $*$ & $*$ & $*$ & $*$ \\
\hline
\end{tabular}

Values are Mean \pm SE $(n=6)$; one way ANOVA

Means with different superscripts in a column differ slightly at $\mathrm{P}<0.05(*)$. 
Table.3 Hematological parameters (TEC, Hb and PCV) in different groups at different time intervals

\begin{tabular}{|c|c|c|c|c|c|c|}
\hline \multirow[t]{2}{*}{ Group } & \multicolumn{2}{|l|}{ TEC } & \multicolumn{2}{|l|}{$\mathrm{Hb}$} & \multicolumn{2}{|l|}{$\mathrm{PCV}$} \\
\hline & Day 14 & Day 28 & Day 14 & Day 28 & Day 14 & Day 28 \\
\hline Group 1 & $2.53 \pm 0.03^{\mathrm{a}}$ & $2.47 \pm 0.03^{\mathrm{a}}$ & $10.73 \pm 0.32^{\mathrm{a}}$ & $12.57 \pm 0.27^{\mathrm{a}}$ & $36.10 \pm 0.21^{\mathrm{a}}$ & $35.20 \pm 0.57^{\mathrm{a}}$ \\
\hline Group 2 & $2.24 \pm 0.04^{b}$ & $2.28 \pm 0.05^{b}$ & $9.53 \pm 0.28^{b}$ & $11.43 \pm 0.41^{b}$ & $32.88 \pm 0.59^{b}$ & $32.60 \pm 0.56^{b}$ \\
\hline Group 3 & $2.22 \pm 0.09^{b}$ & $2.27 \pm 0.02^{b}$ & $9.43 \pm 0.26^{b}$ & $11.28 \pm 0.30^{b}$ & $31.82 \pm 1.60^{b}$ & $32.37 \pm 0.54^{b}$ \\
\hline Group 4 & $2.06 \pm 0.04^{\mathrm{c}}$ & $2.05 \pm 0.10^{c}$ & $9.02 \pm 0.35^{b}$ & $10.53 \pm 0.35^{b}$ & $30.65 \pm 0.88^{b}$ & $29.85 \pm 0.68^{c}$ \\
\hline Group 5 & $2.11 \pm 0.04^{b c}$ & $2.16 \pm 0.05^{b c}$ & $9.68 \pm 0.31^{b}$ & $11.40 \pm 0.26^{\mathrm{b}}$ & $31.67 \pm 0.95^{b}$ & $32.00 \pm 1.15^{b c}$ \\
\hline Group 6 & $2.09 \pm 0.04^{b c}$ & $2.14 \pm 0.05^{b c}$ & $9.65 \pm 0.40^{b}$ & $11.35 \pm 0.33^{b}$ & $32.55 \pm 1.27^{b}$ & $31.88 \pm 0.67^{b c}$ \\
\hline P value & $*$ & $*$ & $*$ & $*$ & $*$ & $*$ \\
\hline
\end{tabular}

Values are Mean \pm SE $(\mathrm{n}=6)$; one way ANOVA

Means with different superscripts in a column differ slightly at $\mathrm{P}<0.05(*)$.

Table.4 Evaluation of MCV, MCH and MCHC in different groups at different time Intervals

\begin{tabular}{|c|c|c|c|c|c|c|}
\hline \multirow[t]{2}{*}{ Group } & \multicolumn{2}{|l|}{$\mathrm{MCV}$} & \multicolumn{2}{|l|}{$\mathrm{MCH}$} & \multicolumn{2}{|l|}{ MCHC } \\
\hline & Day 14 & Day 28 & Day 14 & Day 28 & Day 14 & Day 28 \\
\hline Group 1 & $142.98 \pm 0.94^{\mathrm{a}}$ & $146.03 \pm 0.36^{\mathrm{a}}$ & $44.05 \pm 0.38^{\mathrm{a}}$ & $51.27 \pm 0.30^{\mathrm{a}}$ & $32.12 \pm 0.27^{\mathrm{a}}$ & $36.15 \pm 0.34^{\mathrm{a}}$ \\
\hline Group 2 & $136.82 \pm 1.15^{b}$ & $141.77 \pm 0.65^{b}$ & $40.02 \pm 0.44^{b}$ & $49.38 \pm 0.49^{b}$ & $29.70 \pm 0.54^{b}$ & $35.23 \pm 0.20^{b}$ \\
\hline Group 3 & $136.37 \pm 1.52^{b}$ & $141.27 \pm 0.65^{b}$ & $40.22 \pm 0.30^{b}$ & $49.22 \pm 0.21^{b}$ & $29.77 \pm 0.21^{b}$ & $35.20 \pm 0.24^{b}$ \\
\hline Group 4 & $133.12 \pm 0.95^{b}$ & $138.60 \pm 1.43^{b}$ & $38.55 \pm 0.19^{c}$ & $47.58 \pm 0.69^{c}$ & $28.53 \pm 0.19^{c}$ & $34.17 \pm 0.30^{c}$ \\
\hline Group 5 & $135.07 \pm 1.95^{\mathrm{b}}$ & $139.17 \pm 1.03^{b}$ & $39.50 \pm 0.18^{b c}$ & $48.87 \pm 0.49^{b c}$ & $29.18 \pm 0.22^{\mathrm{bc}}$ & $34.62 \pm 0.43^{\mathrm{bc}}$ \\
\hline Group 6 & $134.80 \pm 1.79^{b}$ & $139.13 \pm 1.99^{b}$ & $39.30 \pm 0.75^{\mathrm{bc}}$ & $48.58 \pm 0.57^{\mathrm{bc}}$ & $28.97 \pm 0.29^{\mathrm{bc}}$ & $34.38 \pm 0.30^{\mathrm{bc}}$ \\
\hline P value & $*$ & $*$ & * & * & $*$ & * \\
\hline
\end{tabular}

Values are Mean $\pm \mathrm{SE}(\mathrm{n}=6)$; one way ANOVA

Means with different superscripts in a column differ slightly at $\mathrm{P}<0.05(*)$.

Table.5 Total Leucocytes Count (thousands/Cmm) in different groups

\begin{tabular}{|l|l|l|}
\hline Group & Day 14 & Day 28 \\
\hline Group 1 & $25.43 \pm 0.24^{\mathrm{c}}$ & $27.15 \pm 0.25^{\mathrm{d}}$ \\
\hline Group 2 & $27.53 \pm 0.61^{\mathrm{b}}$ & $29.63 \pm 0.79^{\mathrm{c}}$ \\
\hline Group 3 & $27.70 \pm 0.70^{\mathrm{b}}$ & $29.98 \pm 0.77 \mathrm{~b}^{\mathrm{c}}$ \\
\hline Group 4 & $31.75 \pm 1.14^{\mathrm{a}}$ & $34.03 \pm 0.75^{\mathrm{a}}$ \\
\hline Group 5 & $30.12 \pm 0.43^{\mathrm{a}}$ & $32.02 \pm 1.30^{\mathrm{ab}}$ \\
\hline Group 6 & $30.43 \pm 0.74^{\mathrm{a}}$ & $32.38 \pm 0.40^{\mathrm{a}}$ \\
\hline P value & $*$ & $*$ \\
\hline
\end{tabular}

Values are Mean \pm SE $(\mathrm{n}=6)$; one way ANOVA

Means with different superscripts in a column differ slightly at $\mathrm{P}<0.05(*)$. 
A significant $(\mathrm{P}<0.05)$ increase in TLC was found in group 2, 3, 4, 5 and 6 treated birds when compared to control which might be due to the activation of leucopoiesis due to administration of intoxicants, which might act as an immunosuppressive agents at this level (Table 5). These findings were in accordance with Yano et al., (2002), Mansour et al., (2007) and Soujanya et al., (2013) which were recorded in rats at different dosage for different time intervals.

In conclusion IM, SPD and its combination resulted in mild, marked and severe hematological changes at different time intervals. The present dose levels (IM @ 50 ppm and SPD @ 1000ppm) were found to be toxic in nature. The co-administration of vitamin E and silymarin @ 20 and 1000 ppm revealed mild improvement in all the above parameter as a part of initiation in repair and regeneration.

\section{References}

Al-saleh, I.A. 1994. Pesticides: A review article. J. Environ. Pathol. Toxicol. Oncol., 13: 151-161.

Hertlein, M., Gary, D.T., Bhadriraju, S. and Christos, G.A. 2011. "Spinosad: A new natural product for stored grain protection". Stored Products, 47: 131146.

Mansour, S.A., Mossa, A.H. and Heikal, T.M. 2007. Haemotoxicity of a new natural insecticide Spinosad on male albino rats. Int. J. Agri. Biol., 9(2): 342-346.

NRC. 1994 Nutrient Requirements of poultry. National Academy press, Washingtion, DC.

Sasidhar Babu, N., Kumar, A.A., Reddy, A.G., Amaravathi, P. and Hemanth, I. 2014. Chronic experimental feeding of imidacloprid induced oxidative stress and amelioration with vitamin $\mathrm{C}$ and Withania somnifera in layer birds. Int. J. Sci. Environ. ISSN and Technol., 3(5): $1679-1684$.

Snedecor, G.W. and Cochran, G. 1994. Statistical methods, 8th ed., IOWA State University Press, Amer, IOWA, USA.

Soujanya, S., Lakshman, M., Kumar, A.A. and Reddy, A.G. 2013. Evaluation of the protective role of vitamin $\mathrm{C}$ in imidacloprid-induced hepatotoxicity in male Albino rats. J. Natural Sci. Biol. Med., 4(1): 67.

Yamamoto, I. and Casida, J. 2009. Nicotinoid Insecticides and the Nicotinic Acetylcholine Receptor. SpringerVerlag: 3-27.

Yano, B.L., Bond, D.M., Novilla, M.N., McFadden, L.G. and Reasor, M.J. 2002. Spinosad insecticide: Sub-chronic and chronic toxicity and lack of carcinogenicity in Fischer 344 rats. Toxicol. Sci., 65(2): 288-298.

\section{How to cite this article:}

Ravikanth, V., M. Lakshman, D. Madhuri and Kalakumar, B. 2017. Haematological Alterations in Broilers Administered with Imidacloprid and Spinosad and Its Amelioration with Vitamin E and Silymarin. Int.J.Curr.Microbiol.App.Sci. 6(4): 496-500.

doi: https://doi.org/10.20546/ijcmas.2017.604.059 